\title{
STRATEGIC ORIENTATION OF THE FIRM and New Product Performance
}

by

\author{
H. Gatignon* \\ AND
}

J. M. XUEREB **

95/60/MKT

(Revised version of $95 / 42 / \mathrm{MKT}$ )

* Professor of Marketing, at INSEAD, Boulevard de Constance, Fontainebleau 77305 Cedex, France.

** Associate Professor of Strategy and Management, at ESSEC, France.

A working paper in the INSEAD Working Paper Series is intended as a means whereby a faculty researcher's thoughts and findings may be communicated to interested readers. The paper should be considered preliminary in nature and may require revision.

Printed at INSEAD, Fontainebleau, France 


\title{
STRATEGIC ORIENTATION OF THE FIRM AND \\ NEW PRODUCT PERFORMANCE
}

\author{
Hubert Gatignon \\ and \\ Jean-Marc Xuereb*
}

June 1995

The authors acknowledge financial support from the Huntsman Center for Global Competition and Innovation of the Wharton School, University of Pennsylvania and wish to thank George Day, Thomas Robertson and Michael Tushman for their comments on previous drafts of this study and John Kimberly and Raymond-Alain Thietart for their help in scale development.

-Hubert Gatignon is Professor of Marketing, INSEAD, France and Professor of Marketing on leave from the Wharton School, University of Pennsylvania; Jean-Marc Xuereb is Associate Professor of Strategy and Management, ESSEC, France. 


\section{STRATEGIC ORIENTATION OF THE FIRM AND}

\section{NEW PRODUCT PERFORMANCE}

\section{Abstract}

This research seeks to understand which of three different strategic orientations of the firm (customer, competitive, and technological orientations) is more appropriate, when, and why, in the context of developing product innovations. We propose a structural model of the impact of the strategic orientation of the firm on the performance of a new product. This impact is hypothesized to occur as a chain of events. Strategic orientation is viewed first as an antecedent of the characteristics of the innovation marketed by the firm. The subsequent market performance of the innovation is hypothesized to be a function of both the innovation's characteristics and the firm's strategic orientation. The ability of the firm to take advantage of its orientation to market the innovation succesfully is also hypothesized to be moderated by the firm's environment.

The results provide evidence for best practices as follows. (1) A firm wishing to develop an innovation superior to the competition must have a strong technological orientation. (2) A competitive orientation in high growth markets is useful because it enables firms to develop innovations with lower costs, a critical element of success. (3) Firms should be consumer oriented and technology oriented in markets where demand is relatively uncertain. These orientations together lead to products which perform better, and the firm will be able to market innovations better, thereby achieving a superior level of performance. (4) A competitive orientation is useful to market innovations when demand is not too uncertain but should be deemphasized in highly uncertain markets. In short, these results suggest that the appropriateness of a given strategic orientation, even a customer orientiation, is not unconditional. 


\section{INTRODUCTION}

The long term profitability of a firm has been shown to be related to the firm's ability to innovate in the strategy, marketing and economics literatures (e.g., Geroski, Machin and Van Reenen 1993, Soni, Lilien and Wilson 1993, Capon, Farley and Hoenig 1990). Recently, the marketing strategy literature has presented evidence that a firm's strategic orientation as a market-driven company (Day 1990) is a significant indicator of its performance, including management's perception of the success of new products (Narver and Slater 1990, Slater and Narver 1994, Cooper 1994). These two issues (i.e., innovating and strategic orientation) are not, however, independent. It is possible that the strategic orientation of the firm leads to, at least in part, superior performance because of the innovations which are brought to market. Indeed, this is consistent with the adoption of innovation research, which indicates that the innovation's characteristics are strong determinants of the adoption of an innovation (Rogers 1983, Gatignon and Robertson 1985). Market orientation, which reflects the broad strategy of a firm, is a concept which does not concern solely the activities which facilitate the understanding of customers' needs. A strong product policy is required to serve better the needs of consumers through the "augmented product" (Levitt 1980, Narver and Slater 1990). The role of the strategic orientation of the firm on the ability to develop successful new products has not been investigated. However, this strategic orientation choice is critical to guide the actions which lead to strong performance. While being market-driven may lead to general benefits for the firms' marketing activities, a direct benefit concerns the ability to bring to market new products which present the characteristics necessary to be successful.

The literature on market orientation includes not only the concept of customer orientation, but also the concept of competitive orientation (Narver and Slater 1990). Both orientations have been considered to have similar effects on performance (Slater and Narver 1994). Competitive effects play an important role in the strategy of firms (Porter 1980, 1985) and more specifically in their innovation strategy and performance (Robertson and Gatignon 1986, Gatignon and Robertson 1993). Furthermore, the commercial performance 
of an innovation is highly linked to a strong R\&D orientation and the use of sophisticated technologies in the development of new products. For example, Cooper $(1984,1979 \mathrm{a}, \mathrm{b})$ finds that one of the most important factors characterizing successful new industrial products is the firm's technological and production proficiency. While the emphasis of the marketing and strategy literatures has been on establishing the importance of the three types of strategic orientations mentioned above (the firm's market orientation, its technological orientation, and its competitive orientation), the critical managerial decision concerns which one(s) should be stressed in a given environmental context. Consequently, the purpose of this research is to understand which strategic orientation should be emphasized in a given context in order to develop successful innovations. More specifically, our objectives are (1) to explain what strategic orientations lead to the development of products with the "right" characteristics and to successful commercialisation and (2) to examine the contingencies which moderate the impact of the strategic orientations on new product success. The contingengy approach explains when a market orientation is helpful, when it is not helpful and what alternate orientation is more appropriate.

Therefore, our study investigates the relationships among a firm's strategic orientation, the characteristics of the innovations brought to market, and new product performance. We broaden the definition of a firm's strategic orientation to include three components: the market orientation, the competitive orientation, and the technological orientation. Our thesis is that the characteristics of innovations as well as their commercial performance depend on the strategic orientation of the firm. Moreover, the importance of each strategic orientation component is viewed as contingent upon the market characteristics facing the firm.

\section{CONCEPTUAL FRAMEWORK}

Traditionally, research on the adoption of innovations and on the performance in the market of these innovations has focused on innovation characteristics (Rogers 1983) and on industry characteristics 
(Robertson and Gatignon 1986, Gatignon and Robertson 1989). These two categories of factors also reflect the basic framework used in strategy research concerned with the commercial performance of innovations (Calantone, Di Benedetto and Divine 1993, Gatignon, Weitz and Bansal 1990). While well recognized by academicians and practitioners as a requirement for business profitability, the strategic orientation of the firm has been studied more recently (Day 1990, Kohli and Jaworski 1990, Narver and Slater 1990). The orientation of the firm has a critical role to play in the commercial performance of a new product. The benefits of a firm's orientation should be directly observed by the characteristics of the innovation itself and on its performance in the market. We now define the types of strategic orientations mentioned above. Then, we discuss how strategic orientation can have an impact on characteristics of innovations and their performance. We also present characteristics of the environment which could provide contingencies relating the firm orientation to innovation performance.

\section{The Strategic Orientation of the Firm}

While the basic marketing concept has advocated a market orientation (Levitt 1960), a recent stream of research has been successful in defining, measuring and developing a theory of market orientation (Day 1990, 1994, Narver and Slater 1990, Slater and Narver 1994, Kohli and Jaworski 1990, Kohli, Jaworski and Kumar 1993). A firm's strategic orientation reflects the strategic directions implemented by a firm in order to create the proper behaviors for the continuous superior performance of the business (Narver and Slater 1990). Three major strategic orientations can be identified from the list of factors which determine the success or failure of new products: the firm's consumer orientation and its competitive orientation-often covered jointly under the label of market orientation--and the firm's technological orientation. While interfunctional coordination has been considered as part of the market orientation concept (Narver and Slater 1990), we follow the organizational behavior literature and define this construct next as an influencial aspect 
of the organizational structure (Thompson 1967) which is necessary for obtaining full benefit from a proper strategic orientation mix.

\section{Customer Orientation}

The concept of "market" connotes many issues, including users' needs (Von Hippel 1986), the identification of segments, buying habits, preferences in terms of features and price, market growth (Cooper 1983), competitors (Porter 1980, 1985) and suppliers (Porter 1985). Research indicates that the commercial performance of new products depends on how well the market opportunity has been identified, analyzed, and incorporated into the product's design (Rothwell 1977, Cooper 1983, Lilien and Yoon 1988, Dougherty 1990). According to the strategy and marketing literatures, all of these issues have to be integrated in the conception and the realization of a new product. For example, Project SAPHO finds that successful innovators understand user needs better than do their failed counterparts (Rothwell et al. 1979). Von Hippel (1988) argues that suppliers and users are the two main functional sources of innovation. Cooper (1983, 1984) suggests that successful new products are developed with a differential advantage and meet customers' needs better than do competitors' products.

According to Narver and Slater (1990), customer orientation is the sufficient understanding of one's target buyers to be able to create superior value for them continuously. Deshpandé, Farley and Webster (1993) define customer orientation as "the set of beliefs that puts the customer interest first." Therefore, in terms of a firm's innovative behavior, a consumer-oriented firm can be defined as a firm with the ability and the will to identify, to analyze, to understand, and to answer user needs. A consumer orientation also emphasizes the identification of possible markets in the case of a technological breakthrough looking for commercial applications. Finally, a consumer orientation helps the firm to learn a large part of the market's technical issues and provides an evaluation of possible segments, of the importance of the market, and of its growth rate 


\section{Competitive Orientation}

A competitor orientation can be defined as the ability and the will to identify, to analyze, and to respond to competitors' actions. This includes the identification and construction of competitive advantages in terms of quality or specific functionalities, and allows the firm to position the new product weil. Such an orientation makes it possible for the firm to understand "the short term strengths and weaknesses and the long term capabilities and strategies of both the key current and key potential competitors" (Narver and Slater 1990) and to react adequately. A competitor orientation is both proactive (when, for example, a firm is looking for a "highly attractive market") and reactive (when it responds to a competitor's action). In a study of innovation processes in the computer industry, Xuereb (1993) shows that a large number of new product developments starts in response to a competitor's action and that product development is subject to the influence of competitors' innovation processes. Competitors do not remain passive when confronted by a competitive innovation but react in order to maintain their relative position (Gatignon, Anderson and Helsen 1989, Robinson 1988). Also, most successful innovative firms select certain types of new products as a function of market competitive characteristics (Cooper 1984). Following the portfolio analysis literature, successful firms avoid the "highly competitive markets" and prefer the "highly attractive markets" characterized by a large market potential, rapid growth, no dominant competitor, and a large number of customers (Cooper 1984). Consequently, a competitor orientation is required for the commercial performance of innovations.

\section{Technological Orientation}

Innovative firms are also strongly $R \& D$ oriented, are proactive in acquiring new technologies, and use sophisticated technologies in the development of their new products (Cooper 1984, Kanter 1988). Cooper (1994) refers to technology-driven organizations. Therefore, a technology-oriented firm can be defined as a firm with the ability and the will to acquire a substantial technological background and to use it 
in the development of new products. This includes the activities of R\&D and technological scanning. Technology orientation also means that the company is able to use its technical knowledge to build a new technical solution in order to answer and meet new needs of the users. Although this orientation has not been part of the strategic orientation research stream, it is a key attribute of technology oriented firms (Workman 1993). Research and development activities are subject to high uncertainty outcomes and factors such as leadership and championship have been identified as contributing to the success of R\&D work (Waldman and Atwater 1994, Shane, Venkataraman and MacMillan 1994). These factors reflect the importance given to research and development and technology in the firm.

\section{Interfunctional Coordination}

Interfunctional coordination refers to the specific aspects of the structure of an organization which facilitate the communication among the organization's different functions: "...an organization must exchange with not one but several elements, each of which is itself involved in a network of interdependence, with its own domain and task environment (Thompson 1967, p. 29)." This construct is conceptually distinct from the strategic orientation of the firm which reflects broad strategic choices. Indeed, organizational behaviorists view coordination and control mechanisms used to link units together as part of the formal organizational arrangements (Nadler and Tushman 1980). The coordinated integration of the firm's resources in creating superior value for customers and the resulting synergistic effects of such coordination are obviously closely tied to the orientations of the firm (Kohli and Jaworski 1990, Narver and Slater 1990). Any individual in any function in a firm can potentially contribute to the creation of value for the customers (Porter 1985). However, the realization of this potential is conditioned by the level of interfunctional coordination. The importance of the coordination of R\&D with marketing is summarized in Griffin and Hauser (1994), who review fourteen studies supporting it. Interfunctional coordination allows communication and exchange between the firm's organizational units which are concerned with the three orientations defined previously (Moenaert et al. 1994). Without interfunctional coordination, the new 
product development process will be ruled by a single preoccupation (a customer, a competitive, or a technological preoccupation), which reduces the innovation's potential performance. Therefore, interfunctional coordination is the mechanism which enables the three necessary strategic orientations to work jointly.

\section{Strategic Orientation and Successful Innovation}

Narver and Slater (1990) have been pioneers in studying the impact of market orientation on firm performance. More directly relevant for innovation effectiveness, Slater and Narver (1994) analyzed the role of market orientation on management perception of new product success relative to all other competitors in the SBU's served market over the last year. These studies confirm that firms which are market-oriented, i.e., both customer and competitor oriented, perform better than the others. An important question, however, which has not been addressed in the context of innovations, concerns the reasons for this finding; is it because these firms are better able to design a better product and/or is it because of a greater general effectiveness in marketing an innovation? An analysis which would test these explanations needs to consider explicitly the characteristics of the innovations being marketed. In this study, we propose to investigate the impact of the firm strategic orientation on the characteristics of the innovations. We argue that certain kinds of innovations are better developed when a firm stresses certain strategic orientations. We also investigate if firm orientation has positive effects in the way that innovations are marketed, beyond the greater performance due to having an innovation with superior characteristics. This conceptual framework is presented in Figure 1. Innovation performance is affected by the innovation characteristics, although the influence of the market environment and the resources of the firm must be controlled for. The three strategic orientations of the firm, in association with interfunctional coordination are viewed as important predictors of the characteristics of the innovations being marketed. The market characteristics and the firm resources are also potential explanations for industry and firm differences in the characteristics of the innovations. The 
strategic orientation and the level of interfunctional coordination of a firm can also influence the ability of the firm to take advantage of a new product to make it successful. Therefore, even after controlling for the innovation characteristics and the other factors mentioned above, firm orientation can have a marginal impact on innovation performance. ${ }^{1}$ These relationships, which are central to this study, are represented by full lines on Figure 1. The other main effects which should be controlled for are represented with dashed lines. The dotted lines on Figure 1 represent the thesis that the role of firm orientation is contingent upon the market environment. We suggest with these dotted lines that the importance (weight) of each type of orientation in determining the innovation characteristics and the success of the innovation may vary depending on the market environment.

\section{Innovation Characteristics and New Product Performance}

The adoption of innovations research provides strong evidence that innovation characteristics affect the likelihood and speed of diffusion and, therefore, the success of an innovation (Gatignon and Robertson 1985). Innovation characteristics have typically been analyzed according to Rogers' (1983) scheme, which proposes that the innovation's relative advantage, compatibility, triability and observability are positively related to adoption and that innovation complexity and perceived risk are negatively related to adoption. However, these characteristics are not independent. Parker and Sarvary (1994) find, using multiple items measuring Rogers' characteristics, that the relative advantage items load consistently on a common factor. One or two other factors are needed in most product categories; however, while they identify complexity as the second factor, the interpretation of the third one varies by product categories. In fact, Gatignon and Robertson (1991) find that "the relevant dimensions of an innovation are not well specified " (p.321). Relative advantage appears as a consistently important product characteristic in explaining adoption (Parker and Sarvary 1994, Holack 1988) and new product success, as evidenced by a large scale recent meta-analysis study which shows that the largest average absolute correlation is indeed with product advantage (MontoyaWeiss and Calantone 1994). This concept of product relative advantage is also central to the strategy 
literature notion of differentiation, which consists of offering a product or augmented product which is better than the competition on some key dimension valued by the customers (Porter 1980).

Another classification ${ }^{2}$ of innovations has been proposed by Robertson (1971), who introduced the concept of an innovation continuum based on the effect of the innovation upon established patterns of consumption (from continuous to discontinuous). While difficult to operationalize due to the difficulty of measuring patterns of consumption, the notion of radical versus incremental innovations offers a similar perspective. In fact, Dewar and Dutton (1986) suggest that perceived risk is an important component of the radicalness of an innovation. However, the radical-incremental distinction is typically made from a technical perspective (Anderson and Tushman 1990). Dewar and Dutton (1986) define radical innovations as "fundamental changes that represent revolutionary changes in technology... Incremental innovations are minor improvements or simple adjustments in current technology" (p.1322-1323). More recently, based on a relatively extensive literature in Organization Behavior, Henderson and Clark (1990) state that "incremental innovation introduces relatively minor changes to the existing product, exploits the potential of the established design, and often reinforces the dominance of established firms... Radical innovation, in contrast, is based on a different set of engineering and scientific principles..." (p. 9). Radical innovations are technological discontinuities that "advance by an order of magnitude the technological state-of-the-art which characterizes an industry" (Anderson and Tushman 1991, p. 27). This concept is difficult to measure, as pointed out by Dewar and Dutton (1986), and is related to the concept of relative advantage because an innovation which is similar to existing products cannot be highly differentiated, and, therefore, cannot have a major advantage over the existing products or competitors. Nevertheless, the technological focus distinguishes the radical-incremental continuum from the consumer benefits point of view inherent in the relative advantage construct. Soni, Lilien and Wilson (1993) refer to the pioneering literature (e.g., Robinson and Fornell 1985, Urban et al. 1986) to argue that firms producing radical innovations perform better than firms producing mainly imitative innovations. Their empirical analysis also supports this relationship. 
Another factor which characterizes the competitive position of a product is its cost (Porter 1980).

The lower the cost, the greater the potential for profits, either by setting higher margins or by penetrating the market with a lower price.

In summary, we propose the following hypothesis:

\section{$\mathrm{H}_{1}$ : The greater a new product's relative advantage, the more radical it is and the lower its cost, the better the performance of this new product.}

\section{Strategic Orientation and Innovation Characteristics}

The strategy pursued by a firm is designed in order to guide management. We propose that a firm's strategic orientation has a significant impact on the characteristics of innovations which are introduced to the market. In general, marketing theory predicts that firms which are customer oriented serve better the needs of the consumers, especially by providing products which fit their needs best (Griffin and Hauser 1993, Day 1991). This clearly creates an advantage for the product. However, this advantage is only assessed comparatively to the competitors' products. While originally considered as an implementation issue of the marketing concept, competition is now viewed as an integral part of the definition of the marketing concept in terms of satisfying the needs and wants of consumers more effectively and more efficiently than competitors (Kotler 1976). This is a recognition of the need for a competitive orientation at the same time as a customer orientation. The satisfaction of the needs is achieved by providing a product perceived by consumers as fitting their needs better than does the competition. Therefore, products which provide a strong advantage should be the result of a deliberate strategy within the organization as reflected by a customer and competitive orientation (Cooper 1988).

The third orientation, technology, is not part of the definition of the marketing concept. In fact, a technological orientation can be the result of a product-oriented management which focuses "energy on making good products and improving them over time" (Kotler 1984, p.17). However, the level of technology involved in most industries has been accelerating (Kelly 1994). Most studies in strategy concemed with core competencies involve high technology industries where the investments required contribute to the 
importance given to technology in the organization. Therefore, while these high-technology industries must have a technology focus, it might be the case that industries with lower levels of technology do require a certain level of technology orientation as well.

In addition to the ability to produce innovations with a greater competitive advantage, a technological orientation should lead to more radical innovations. Discovering radical innovations requires a strong technological leadership which results from a well defined technology strategy (Porter 1985). At the same time, although the technology strategy could be designed to obtain cost advantages, a strong benefit of imitation strategies is to avoid R\&D costs (Schnaars 1994). Therefore, typically, a technological orientation leads to a smaller emphasis on innovation costs, at least when the innovation is introduced.

Finally, competition not only is a strong force to differentiate products so that they satisfy demand better than the competitors', but it also draws management attention to cost efficiencies so that the firm would be more profitable and have more resources to compete. Therefore, firms with a strong competitive emphasis should design innovations with costs in mind which are expected to be lower than the costs of innovations designed by less competitively oriented firms. Consequently, we advance the following hypotheses:

$\mathrm{H}_{2}$ : The more customer, competitor and technology oriented firms are, the greater the relative advantage of their innovations. These three orientations (customer, technological and competitive) are all needed for designing innovations which have a strong relative advantage.

$\mathrm{H}_{3}$ : The more technology-oriented firms are, the more radical their innovations and the higher the innovation cost.

$\mathbf{H}_{4}: \quad$ The more competition-oriented firms are, the lower the costs of their innovations.

In the discussion above, the need for a balance between the three types of orientation within a firm has been identified. While synergies have been proposed in $\mathrm{H}_{2}$, the benefits of these synergies might not be realized without them being managed properly. The role of integrating mechanisms across departments, especially between marketing and R\&D, has clearly been demonstrated (Griffin and Hauser 1994, 1992). 
This concept of interfunctional coordination has also been included in the strategic orientation marketing literature. Narver and Slater (1990) consider this concept as an aspect of the market orientation construct. In fact, we view the role of coordination mechanisms to be one of enhancement of the benefits associated with a combination of orientations. Consequently, interfunctional coordination is a separate construct which enhances the synergies that may exist by having a properly balanced orientation. Therefore,

\section{Ho: Interfunctional coordination enhances the synergies between the three types of orientation to design innovations which have a strong relative advantage, which are more radical, and which have a lower cost.}

\section{Strategic Orientation and New Product Performance}

We have disclussed why the three types of orientation can be beneficial to a firm's innovative strategy. This should be reflected in a better response from the market and therefore should lead to a more successful new product. This could explain the resuits of Narver and Slater (1990) and Slater and Narver (1994). However, if the effects of strategic orientations are recursive, i.e., due to their impact on the innovation characteristics, once controlling for innovation characteristics, it is not clear that firm orientation should influence performance, or at least it should not be as large. Such an effect, beyond the impact of firm orientation already considered through the innovation characteristics, would indicate that the orientation of the firm affects more than the product development process. In fact, the marketing concept argues that the product is only a part of the marketing activities and that a customer orientation especially should improve the ability of the firm to serve "effectively and efficiently" the needs of the consumers. These effects are represented by the fact that the firm orientations have an impact on new product performance above the impact realized on the innovation itself. We can summarize these arguments into the following hypothesis:

$\mathbf{H}_{6}$ : Interfunctional coordination enhances the interactions between the three types of orientation necessary to market successfully an innovation. 


\section{Market Characteristics}

The success of an innovation is not independent of the market in which the firm functions. Indeed, a number of market characteristics have a direct impact on the performance of new products. For example, it is more difficult to successfully introduce a new product in a highly competitive market, in part because competitors can react very strongly (Gatignon, Anderson and Helsen 1989, Robinson 1988). In addition, consistent with Kohli and Jaworski (1990)'s propositions and Slater and Narver (1994)'s hypotheses, the effectiveness of a firm's orientation is conditioned by the nature of its market. Slater and Narver (1994) considered these interactions in a model of firm performance (including overall perceived new product performance, as indicated earlier) as a function of customer and competitive orientation. The lack of significance of the interactions lead them to conclude that "it would be risky for a manager to attempt to adjust the business's market orientation to match current market conditions" (p.54). While it is difficult to control for the innovations being marketed when evaluating the performance of a group of new products, failing to account for these product attributes can bias the estimates of the effects of firm orientation; indeed, the new product attributes might not be independent of the firm strategic orientations. In fact, it is our contention, as hypothesized above, that firms with different strategic orientations design and bring to market innovations with different characteristics. Market characteristics hypothesized to have an impact on the commercial performance of innovations and on the required level of the firm's orientation are: market growth, competitive intensity and demand uncertainty. We now discuss the main effects and the interactions with strategic orientation of the market characteristics, although only the hypotheses regarding interactions are formally stated ${ }^{3}$

\section{Market Growth}

According to Scherer (1980), when market demand is growing, it is easier for all sellers to acquire and retain customers and eam profits. Therefore, a positive relationship exists between market growth and 
the innovation's performance (Cooper 1984). In addition, growing markets are at the early stages of the product life cycle. Consequently, little information is available on these markets at the same time as consumers are developing preferences (Carpenter and Nakamoto 1989). Therefore, a strong consumer orientation is necessary to understand these newly created markets. Furthermore, competitors are particularly attentive to each others' moves in high growth markets where strong competitive rivalry has been observed (Ramaswamy, Gatignon and Reibstein 1994, Robinson 1988); therefore, a strong competitor orientation is necessary to track and anticipate competitive activities.

$H_{7}$ : Compared to slow growing markets, a stronger consumer orientation and a stronger competitive orientation are required in fast growing markets to achieve a similar level of performance.

\section{Competitive Intensity}

The notion of competitive intensity in a market connotes many issues, such as buyer power, supplier power, entry barriers, and industry concentration (Bain 1959, Porter 1980, Scherer 1980). Competitive intensity reduces new product performance (Cooper 1984, Narver and Slater 1990). So, in a highly competitive market, the firm needs a strong competitive orientation to identify the competitors' strengths and weaknesses, to develop competitive advantages, and to anticipate competitors' reactions. Consequently, the required level of competitive orientation of a firm has to be highly linked with the competitive level of the markets in which the firms operate (Kohli and Jaworski 1990, Gatignon and Robertson 1991).

The nature of the innovations should also be affected by the level of competition intensity. In particular, management must pay greater attention to costs in a competitively intense market, partly because of the greater pressure on prices (Porter 1980). Although this main effect is not formally stated as an hypothesis, it should be controlled for.

In summary:

$\mathrm{H}_{\mathbf{x}}$ : Compared to less competitive markets, a stronger consumer orientation and a stronger competitive orientation are required in highly competitive markets to achieve a similar level of innovation performance. 


\section{Demand Uncertainty}

Demand uncertainty is directly related to the notion of market turbulence, which Kohli and Jaworski (1990) propose as a moderator of the market orientation-business performance linkage. When demand is uncertain due to changing consumers or changing preferences among consumers, a customer orientation is necessary to facilitate learning about both the customer's needs and the customer's buying incentives. This concept of demand uncertainty is similar to Albernathy's notion of target uncertainty (Albernathy 1978). He argues that reducing this uncertainty is critical to enhance the attractiveness of investing in risky $R \& D$ efforts. Workman (1993) argues that, when it is not possible to predict what consumers will want, the role of marketing in the new product development process is limited and the optimal strategy might be to pursue many R\&D alternatives and to be ready to develop a strategy when more information becomes available. This strategy increases the costs of new product development. While the role of marketing is still important to provide this new information over time, this reasoning points out the need for having a strong technolog: orientation.

Consequently,

$H_{9}$ : In markets where demand is uncertain, a stronger consumer orientation and a stronger technology orientation are required than in markets where demand uncertainty is low in order to achieve a similar level of performance.

\section{Firm Resources}

The industrial organization and marketing strategy literatures place considerable emphasis on the size of a firm, especially because of the resource advantages that it possesses and can use to compete. This factor can strongly affect a new product's performance (Day 1984, Narver and Slater 1990). The greater the resources of a firm, the more market power, a competitive advantage which translates into better performance of the new product. This is due, for example, to immediate access to distribution. A firm with large resources could also be a signal of commitment to consumers who face uncertainty and who, therefore, might respond more favorably. These advantages can be due also to the ability to invest greater resources into the 
design of superior innovations (Capon et al. 1992), which might be more radical, have a greater relative advantage, and might cost less. These effects are not central to our study, but need to be included in a model of the impact of strategic orientations.

\section{EMPIRICAL ANALYSIS}

\section{Data}

Narver and Slater's research (1990) shows that a survey by questionnaire is feasible to collect valid and reliable data about a firm's orientation. Our data were obtained from a large scale mail survey. A questionnaire was sent to 3000 marketing executives drawn randomly from a commercially available list in a broad cross-section of industries. One hundred ninety eight questionnaires were not delivered and 393 were returned completely filled.

The unit of analysis is the last new product introduced in the market by a Strategic Business Unit. ${ }^{4}$ The questionnaire was filled out by marketing executives who have been shown in past research to be knowledgeable key informants about the information concerning new product development (Xuereb 1993).

In order to verify that the questionnaire was reasonable in length and that the respondents did not have any difficulty with any of the questions, a pre-test of the questionnaire was performed on a few marketing managers. Based on their responses, some questions were re-worded. Then, a pilot test of the questionnaire was performed to assess the validity of the scales. A market research company called marketing executives to obtain their agreement to participate in the study and to verify that the respondent was qualified (i.e., was familiar with the latest new product introduction and with the business in which this innovation took place). Out of a list of 300 names, 239 managers were able to be contacted. Of these 239 marketing executives, $87.5 \%$ (209 managers) agreed to participate in the study. A survey was then mailed to these managers, with a letter reminding them of their agreement to participate. A total of 38 managers filled the questionnaire, after one reminder letter. This results in an $18 \%$ response rate of those who had agreed to 
participate, or $16 \%$ of the total of individuals sampled. Because this final response rate is not significantly different from large scale surveys which do not contact managers by telephone first, the final questionnaire was sent directly to the sample. A lottery for a $\$ 500$ award was offered. A reminder questionnaire was sent two weeks later. A total of 393 questionnaires were returned, which gives a $14 \%$ response rate after deducting questionnaires which did not reach the addressees. This rate is similar to the rate reported in the marketing literature (Gatignon and Robertson 1989). An analysis of characteristics of firms indicates no significant differences between respondants and non respondants. Also, no statistical difference appear between early and late responses. Consequently, there is no indication of response bias in our sample (Armstrong and Overton 1977)

Our sample consists of consumer durable goods, consumer packaged goods, consumer services and industrial technology and computer firms. Table 1 presents the distribution of the observations by classes of industry, showing the variety which contributes to the generalizability of the results.

\section{Measures}

Multiple item scales were developed based on items previously proposed and used successfully in survey research studies (Miller and Friesen 1982, Saxe and Weitz 1982, Narver and Slater 1990, Slater and Narver 1994). Because of the availability of several scales used in the literature, a combination of these previously used items was included in the questionnaire, except for avoiding repetitive questions. The exact measures and the corresponding questions are listed in Table 2, with the reliability coefficients. All scales are unidimensional, as items load on a single factor.

\section{Endogenous Variables}

Innovation Success. Consistent with the literature, the commercial performance of a new product is measured by perceived measures (based on multiple items) such as the degree to which the new product's objectives have been achieved (e.g., Moenaert et al. 1994), which are relative to competition and expectation 
within the industry (Deshpandé, Farley and Webster 1993). This should remove industry specific main effects. The measure of innovation success is highly reliable with a coefficient alpha of $0.82 .{ }^{6}$ Although selfassessment measures are prone to potential bias, they are the most commonly used form of performance assessment in marketing strategy research (Saunders. Brown and Laverick 1992). In fact, they may be less problematic than more "objective" financial measures which can also be biased "because of the ulterior motives for which they are produced" (Saunders, Brown and Laverick 1992, p.184). Moreover, financial data is rarely available for the new product but only at the aggregate level. Also, marketing managers are typically the informants with the greatest knowledge of their own business and performance. Finally, a number of studies have demonstrated the convergent ralidity of such scales (Doyle, Saunders and Wright 1989, Dess and Robinson 1984, Venkatraman and Ramanujam 1986).

Innovation characteristics. The innovation is characterized by four dimensions: the relative advantage of the innovation, its relative cost, its radicalness, and the degree of similarity with the competitors' products. While the radical-incremental concept is based on technology, from the consumer's point of view, a competitively-based measure might be more appropriate. Although related to the notion of relative advantage, this measure focusses on the product itself rather than on its benefits, which are found in the relative advantage measure.

- Relative advantage: the innovation advantage is assessed relative to competitive product offerings. It represents the various sources of competitive advantages for a product in terms of product attributes, benefits, and image. These different sources of advantages are not theoretically correlated. Therefore, our measure is a formative index rather than a reflective scale. Nevertheless, all the items (including a general item for overall competitive advantage) load on a single factor and the additive scale has a reliability alpha of 0.74 .

- Radicalness: concerning the radicalness of the new product, a separate analysis was performed using experts in innovation research. Two experts were asked to supply names of radical and of incremental 
innovations. Then, each was asked to rate the innovations named by the other on the items used in the survey. The innovation radicalness scale was highly reliable across innovations and expert $(\alpha=.976)$ and an Analysis of Variance was performed to test for statistical significance across the two categories of innovations labeled radical or incremental by the experts. This analysis supports the validity of the scale to discriminate between radical and incremental innovations. The items of the scale concern the discrepancy between the technology of the innovation and the existing technologies. They are also reflecting the impact that the innovation has on the industry. The reliability of this measure is 0.84 .

- Degree of similarity with competitor's products: this additional measure of how different the innovation is differs from the radicalness scale because of its competitive focus. Conceptually, the arguments developed in the theoretical section can be expressed in general terms of the radicalness of the technology or more specifically relative to the other products which are competing with the innovation. A factor analysis of the items of the radicalness scale with the items expressed relatively to competition revealed the existence of two factors. Therefore, a separate scale of the degree of similarity with the competitors' products was developed with a reliability coefficient of 0.78 . Even though these two scales are correlated $(p=-0.43)$, the impact of both of them was analyzed and the possibility of multicollinearity was assessed.

- Relative cost: The relative cost of the innovation refers to the major sources of cost relative to competitors' products. These sources include marketing costs, manufacturing and operations costs and research and development costs. These costs with an overall evaluation of costs form a single dimensional scale with a reliabity alpha of 0.73 .

\section{Explanatory Variables}

A few recent studies have developed measures of market orientation, long term focus, profit emphasis, and interfunctional coordination. As mentioned above, we included in our measures a 
compilation of the items proposed by Narver and Slater (1990), Kohli, Jaworski and Kumar (1993) and Deshpandé, Farley and Webster (1993). In addition, we added items to measure technological orientation.

Consumer orientafion. Items were developed based on the existing scales which concern the proactivity in users' needs identification (Saxe and Weitz 1982), the degree of identification of user needs and the capacity to analyze this information (von Hippel 1988, Narver and Slater 1990, Slater and Narver 1994), with a will to answer the needs of the users (Saxe and Weitz 1982). The compilation of items used in a number of scales developed by different authors did not reveal a single factor analytic structure. This can be explained by the fact that much of these items represent different ways in which a firm can contribute to a consumer orientation; therefore, these items are formative of an index rather than reflective of an orientation. Consequently, we adopted Narver and Slater's scale and found a similar reliability coefficient of 0.85 . The items do load on a single factor.

Competitor orientation. As described above, the concept of a competitor orientation reflects on the part of the SBU a pro-activity in identifying competitors' actions, the capacity to understand competitors' actions and the will and the capacity to respond to competitors' actions. Narver and Slater's (1990) scale of competitor orientation parsimoniously reflects these notions. The four items that they propose load on a single factor and the reliability alpha $(0.60)$ is only slightly lower than in their samples.

Technology orientation. Our measure of technology orientation includes items which represent the use of sophisticated technologies in new products development (Van de Ven 1986), the rapidity of integration of new technologies (Kanter 1988), and a pro-activity in developing new technologies (Burgelman and Sayles 1986, Garud and Van de Ven 1989) and in generating new product ideas (Kanter 1988). When factor analyzed, the items load on two factors which split according to whether or not items are competitively framed, i.e., based on competitive benchmarking. Because this split is attributable to wording of the items rather than a conceptual difference, all factors were used to form a scale which provides a reliability of 0.89 
Inferfunctional coordination. A scale of interfunctional coordination has been developed by Narver and Slater (1990). The scale includes items concerned with the extent to which all functions contribute to customers' value, the degree of functional integration in the strategy and the degree of utilization of integrative mechanisms (Miller and Friesen 1982). The reliability of 0.77 is slightly above the reliability found by Narver and Slater (1990) in their samples.

Market characteristics. Market growth is measured by the reported growth rate of the market at the time of the new product launch. Demand uncertainty is a four-item scale with a reliability alpha of 0.60 concerned with the ability to predict preferences, tastes and demand levels. Competition intensity refers to the competitive behavior or rivalry between the competitors. Three items form a scale with a 0.75 reliability.

Relative Resources of the firm. The resources of a firm are measured in terms of resources for marketing, distribution and sales force and R\&D. Associated with an overall assessment of the resources of the firm compared to the competitors in the product category, the scale has a 0.83 reliability:

\section{The Model}

Figure 1 represents the conceptual model of how the orientation of the firm can affect the performance of a new product. The relationships between the various constructs are expressed in equations (1), (2) and (3):

$$
\begin{aligned}
& A(i)=e^{\beta_{10}(i)} \operatorname{TO}(i)^{\beta_{11}(i)} C p O(i)^{\beta_{13}(i)} \operatorname{CO}(i)^{\beta_{13}(i)}\left[_{k=1}^{3} M_{k}(i)^{\beta_{14 k}}\right] \operatorname{RES}(i)^{\beta_{15}} e^{0_{1}(i)} \\
& \left.S(i)=e^{\beta_{20}(i)} \operatorname{TO}(i)^{\beta_{21}(i)} C_{P O} O(i)^{\beta_{23}(i)} \operatorname{CO}(i)^{\beta_{23}(i)} \prod_{k=1}^{3} M_{k} C_{k}(i)^{\beta_{21} k}\right] \operatorname{RES}(i)^{\beta_{25}} e^{0_{2}(i)} \\
& R(i)=e^{\beta_{30}(i)} \operatorname{TO}(i)^{\beta_{31}(i)} C_{p} O(i){ }^{\beta_{32}(i)} \operatorname{CO}(i)^{\beta_{33}(i)}\left[_{k=1}^{3} M_{k}(i)^{\beta_{34}}\right] \operatorname{RES}(i)^{\beta_{35}} e^{D_{3}(i)} \\
& \mathrm{C}(\mathrm{i})=e^{\beta_{40}(i)} \mathrm{TO}(\mathrm{i})^{\beta_{41}(i)} \mathrm{CPO}_{\mathrm{P}}(\mathrm{i})^{\beta_{42}(i)} \mathrm{CO}(\mathrm{i})^{\beta_{43}(i)}\left[_{k=1}^{3}{ }_{k} \mathrm{MC}_{k}(\mathrm{i})^{\beta_{44 k}}\right] \operatorname{RES}(\mathrm{i})^{\beta_{45}} e^{\mathrm{D}_{4}(\mathrm{i})}
\end{aligned}
$$

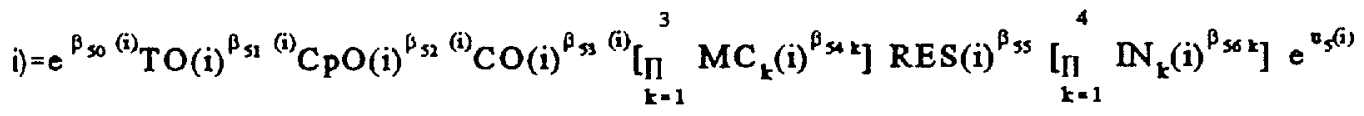




$$
\begin{gathered}
\forall j=1, \ldots, 5: \quad \beta_{j 0}(i)=\alpha_{j 00}+\alpha_{j 01} \operatorname{IC}(i) \\
\forall j=1, \ldots, 5 ; \forall m=1,2,3: \quad \beta_{j m}(i)=\alpha_{j m 0}+\alpha_{j m k} \sum_{k=1}^{3} M C_{k}(i)
\end{gathered}
$$

where:

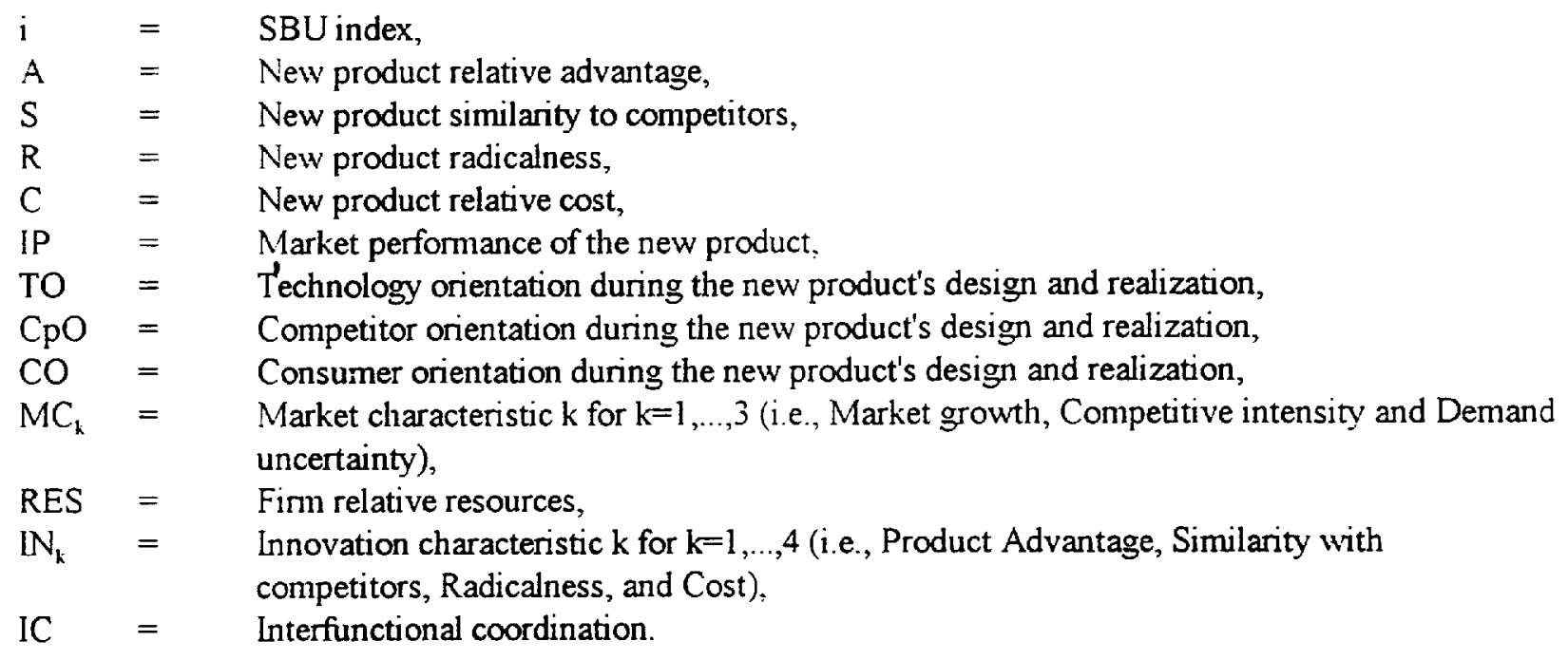

The first four equations in (1) represent the proposition that the characteristics of an innovation marketed by a firm are the result of the firm orientation expressed in terms of the degrees of technological, consumer and competitor orientation involved by the firm or strategic business unit during the design and realization of the new product. The fifth equation in (1) expresses the fact that the performance of the new product might be affected by the same factors, although the innovation characteristics are hypothesized to be an important determinant of its performance in the market. The resources of the firm are also specified to affect each of these five endogenous variables (new product characteristics and innovation performance). A multiplicative functional form represents the interaction between the three orientations. Because the measures are interval scales, it is necessary to transform them in order to be able to perform a meaningful multiplication of these scales. Cooper and Nakanishi (1983) proposed the zeta transformation which has 
been used successfully in the literature (e.g., Anderson 1985). A linear model was also estimated but is not discussed further due to a poorer fit.

The role of interfunctional coordination is modeled as per equation (2). The scaling factor which multiplies the effects of the predictor variables should increase when interfunctional coordination increases. This equation represents the synergistic effects of having high levels on any single orientation.

Equation (3) represents the interactions between the market characteristics and the orientation of the firm. Even though there is no formal hypotheses about the moderating role of market characteristics on the relationship between strategic orientation and the innovation characteristics, equation (3) is generalized to the five equations in (1) in order to empirically assess the existence of such interactions. A test that these interactions are significantly different from zero is performed for each equation, as reported below.

Equations (2) and (3) can be inserted into equation (1) for estimation. The five basic equations shown in (1) represent a block recursive system of equations where the fifth equation can be estimated using Ordinary Least Squares, independently of the first four equations. Also, because the first four equations have the same explanatory variables with no simultaneity, even though the error terms might be correlated, the OLS estimator is identical to the GLS estimator. Seemingly unrelated regression was used to re-estimate the model with only the significant variables to take into account the possible correlations within SBU of the error terms of the four equations corresponding to the innovation characteristics. However, the results were identical. This lack of significance of the error terms across equations tends to demonstrate the lack of firm or industry-specific effects, beyond those specified in the model. Consequently, the Ordinary Least Square estimates are reported.

\section{Results}

The equations were first estimated with the full specification expressed in equations (1)-(3). ${ }^{7}$ They were also estimated by restricting the interaction terms to be zero so as to test for the significance of moderating effects. If these interaction terms were insignificant, a further test was made to check for the 
significance of the market characteristics. These chi-squares test (Chow 1960) results are different for each equation. The product advantage equation is best specified as a main effect model without effect due to market characteristics. The product radicalness and product similarity models indicate no interaction terms are significant; however, market characteristics should be included. The product cost model specification tests indicate that the interactions should not be restricted to zero and the same result applies to the innovation performance equation. The parameter estimates from these model specifications are reported in Table 3. The fit statistics indicate similar fits of the five equations with $R^{2} s$ in the range of 0.15 to 0.37 . The performance equation has the best fit, as could be suspected from the difficulty of explaining the output of R\&D (Gatignon, Weitz and Bansal 1990). Nevertheless, the results show that the variables specified in the theoretical framework provide a statistically significant explanatory power.

The product relative advantage is significantly affected by the technological orientation of the SBU. The greater the firm's technology orientation, the greater the product advantage offered by its innovations ( $\beta$ $=0.27, p<0.01$ ). This is consistent with hypothesis 2 . The level of resources of a firm also affects the degree of advantage of the innovation: the greater the resources, the greater the relative advantage $(\beta=0.21$, $\mathrm{p}<0.01$ ), as discussed above.

Both the product radicalness and the product similarity with its competitors are significantly affected by the degree of technological orientation. The greater the technological orientation, the greater the radicalness of the innovation being brought to market $(\beta=0.61, p<0.01)$ and the more dissimilar the innovation is from its competitors $(\beta=-0.33, p<0.01)$, following our proposed hypothesis 3 . Also, for both innovation characteristics (radicalness and similarity), demand uncertainty has a significant impact. The greater the demand uncertainty, the more radical the product is $(\beta=0.12, p<0.01)$ and the less similar to the competitors' products $(\beta=-0.12, p<0.05)$. This reflects the innovative character of uncertain markets: innovations occur in periods of turbulance before standards emerge. In addition, the degree of similarity of the innovation with the competitors' products is higher in high growth market $(\beta=0.02, p<0.05)$, although 
the radicalness of the innovation is higher in such growth markets $(\beta=0.02, p<0.05)$. This means that new product offerings in high growth markets tend to be using different technologies but which do not provide very differentiated brands. The finding about the greater similarity with competitive products is consistent with the literature on dominant designs discussed earlier. However, the result about the radicalness of the innovation tends to indicate that the firms bringing new products to market which are in the early stages of high growth have invested in different technologies. A dominant technological design has not been defined completely yet. The degree of similarity of the innovation with the competitors' products is also found to be higher in competitively intense markets $(\beta=0.13, p<0.01)$. This result corresponds to the fact that, even though it is necessary to differentiate a brand from its competitors in competitive markets, the competition is partly due to the difficulty of differentiating products in these markets. Furthermore, interfunctional coordination enhances the impact of the strategic orientations in developing innovations less similar to the competitors' products, as predicted in hypothesis $5(\beta=-0.11, p<0.05)$.

The cost of innovations depends on the strategic orientation of the firm. First, as proposed in hypothesis 3 , firms which have a technological orientation have higher costs than their competitors $(\beta=$ $0.18, \mathrm{p}<0.05$ ). This follows directly from the investments required to develop new technologies. The results also indicate that the cost of innovations increases as the firm's competitive orientation increases in declining markets. ${ }^{8}$ However, in high growth markets, hypothesis 4 that a competitive orientation decreases the costs of the innovations $(\beta=0.015, p<0.01)$ is supported. The competitive pressures are a significant force driving costs down in growing markets. In declining markets, a competitive orientation which lead firms to strong rivalry and counter-attack increases the costs. The total costs of the innovations are also higher in uncertain markets $(\beta=0.12, \mathrm{p}<0.05)$, as would be expected from the deployment of greater $R \& D$ activities. Finally, the firms with large resources do not pay as much attention to costs and market innovations which have significantly higher costs $(\beta=0.15, \mathrm{p}<0.01)$. Although these firms would have the ability to invest in 
cost reduction projects, cost is not as critical an issue for them as it would be for a firm with limited resources which must generate high margins to compete.

The performance of the innovation is directly related to the innovation characteristics. The greater the product advantage $(\beta=0.32, p<0.01)$, the greater the product radicalness $(\beta=0.21, p<0.01)$, the smaller the product similarity with its competitors' $(\beta=-0.12, \mathrm{p}<0.05)$ and the lower the product costs $(\beta=-0.28$, $p<0.01$ ), the better the perceived performance of the innovation. This supports our arguments stated in hypothesis 1. Although somewhat correlated, as indicated in the measures section, both the similarity of the innovation with competitive products and the radicalness variables contribute to explaining the innovation performance. Excluding one of them does not affect the other factors.

The role of the strategic orientation of the firm beyond the influence it might have on the innovation characteristics depends. as stated in hypothesis 9 , on the uncertainty level inherent in the market's demand. In highly uncertain markets, the greater the consumer orientation, the greater the performance of the innovation. The role of consumer oriented marketing activities is then critical to gather information which reduces the uncertainty level. However, as demand uncertainty decreases, a very high consumer orientation detracts from performing. This is the result of the positive coefficient of the interaction between consumer orientation and demand uncertainty $(\alpha=0.185, p<0.05)$. Since in our sample the demand uncertainty scale varies between -2.0 and +2.0 , a negative number (which indicates that it is relatively easy to forecast and predict consumers' tastes and preferences) multiplied by the positive coefficient makes the influence of consumer orientation negative, but positive for a large demand uncertainty. This is consistent with Narver and Slater's (1990) findings that consumer orientation has a positive effect for differentiated markets but a negative effect in commodity markets which might be easier to understand.

The value of a technological orientation also depends on demand uncertainty (hypothesis 9). In uncertain markets, a technological orientation improves the performance of the innovation; however, in 
markets where demand is relatively easy to forecast, the more technology oriented a firm is, the worse the performance of the innovation $(\alpha=0.186, \mathrm{p}<0.05)$.

A competitive orientation has also a significant impact on the innovation performance, but the direction of this impact also depends on the level of demand uncertainty in the market $(\alpha=-0.270, p<0.01)$. In a market where demand is easy to forecast and predict (a negative number for low uncertainty levels), a high competitive orientation benefits the performance of the innovation. However, if demand uncertainty is high (positive value on the scale), a competitive orientation hinders the performance of the innovation.

The performance of an innovation is also perceived better by managers from firms which have more resources than their competitors $(\beta=0.14, p<0.01)$. Finally, following hypothesis 6 , interfunctional coordination is almost significant at the 0.05 level $(\alpha=0.096, p<0.065)$, which would tend to indicate that it reinforces the impact of the strategic orientations.

In summary, the strategic orientation of the firm has a significant impact on the performance of new products. This influence is exerted through the innovation characteristics which are being brought to market Firms with different orientations tend to market different types of innovations. This influence, however, is not uniform regardless of the market characteristics. It does depend generally on the uncertainty of demand as well as on the grouth of the market:

- The firm's technological orientation plays the most significant role in determining the innovation's characteristics. The greater the firm's technology orientation, the greater the product advantage offered by its innovations, which are more radical and less similar to the competitors' products, although these innovations are more costly. The role of technology orientation appears unconditional: more is better in any kind of market, even a stable market. Therefore, a firm wishing to develop an innovation superior to the competition benefits greatly from a strong technological orientation.

- In markets which are highly uncertain, a consumer orientation has a positive influence on the commercial performance of the innovation. The development of a new product in a highly uncertain 
environment creates the need for more market scanning and networking with users to identify customer needs. Therefore, the role of consumer oriented marketing activities is critical to gather information, which reduces the otherwise overwhelming level of uncertainty over expected levels of demand.

\section{However, as demand uncertainty decreases, a very high consumer orientation actually}

detracts from performance. In a low uncertainty environment (i.e., one in which demand is stable and well understood), all the competitors will have access to the same information about the market regardless of their level of consumer orientation. Therefore, a firm with a strong consumer orientation will not derive any specific benefit that the competitors would not have as well. However, the firm will incur all the costs associated with these marketing activities.

- It is actually a competitive orientation, not a customer orientation, which leads to superior innovation performance when demand is not highly uncertain. When demand uncertainty is low, both the firm and its competitors can assess the consumers' needs relatively accurately. Therefore, the key success factors of an innovation cannot be derived from a consumer orientation. These factors must be found relative to competitors' products and projects. In markets where demand uncertainty is lower, a competitive orientation allows the firm to study the characteristics and the positioning of its competitors' products. This enables the competitively oriented firm to position and market its new products better, which enhances the products' performance.

\section{- In contrast, a competitive orientation is actually detrimental to the innovation's}

marketplace performance when demand is very uncertain. In a situation of high demand uncertainty, ali firms have a hard time figuring out what the real market is and what users' needs are. What is needed here is a customer orientation. But exclusively competitively oriented firms tend to fall back on improper reliance on competitors' projects and products to infer market needs. The data indicate that a strong competitive orientation is negatively associated with innovation success in such a case. 
- Results indicate that a competitive orientation enables the firm to do what it takes to reduce the innovation's cost in high growth markets. Competitively oriented firms seem able to muster the willpower to cost cut, rather than relying on product features to sustain high prices and justifying cost inefficiencies by product features.

- But results also indicate the story is different in declining markets. It appears that in declining markets, as the firm's competitive orientation increases, the cost of the firm's innovations also increases. A competitor orientation serves to draw management attention to cost efficiencies so that the firm would be more profitable and have more resources to compete. Therefore, firms with a strong competitive orientation tend to design innovations with total costs (production, R\&D, SGA, and marketing) in mind. Once the innovative product is designed, the competitively oriented firm follows a strategy of price and cost cutting. Part of this strategy involves strong rivalry and counter-attack, which drives up costs in the short run. The firm tends to recover these costs and to find itself well positioned in a growing market. But in declining markets, a competitive orientation leads firms to increase the innovation's total costs (production, R\&D, SGA, and marketing) via competitive warfare, in spite of the fact that sales are declining. Such markets do not warrant competitive warfare, yet the competitively oriented firm seems unable to resist the temptation to battle, even while market sales are declining.

- It is striking that our data indicate that having a customer orientation does not have a significant impact on the innovation's characteristics! This is critical, as the data indicate, not surprisingly, that these characteristics are themselves the main factors explaining the new products' commercial performance. It is puzzling that consumer-oriented firms don't differ in the kinds of innovative products they bring to market. Why? What appears to be happening is that a customer orientation resides in the marketing department, which in turn appears to have trouble communicating market considerations to R\&D. This result confirms the observation of Workman (1993). 
In principle, interfunctional coordination is the solution to this problem. Yet, we examined several aspects of interfunctional coordination (which involves information shared among functions, functional integration in strategy, and so forth) and found that firms with better interfunctional coordination do not seem able to do a better job of reaping the benefits that should be derived from having a consumer orientation. Apparently, such coordination is not enough to breach the barriers between functions when it comes to transmitting a customer orientation. However, our results do indicate that interfunctional coordination has one effect: it contributes to the development of innovations which are differentiated from the competitors' products.

\section{CONCLUSION}

Although the basic concepts involved are at the foundation of the marketing concept, this research concems a relatively new area of marketing strategy. The role of the organization's strategic orientation on new product development is central to the performance of a firm. Advocates of market-orientation have recently developed a conceptualization of the antecedents and consequences of the organization's strategic orientations. Yet, empirical research on these issues remains in its infancy. The recent development of measures of the key concepts are a critical step which enables further empirical test of marketing strategy theories. This paper provides some support for the moderating effect of some market characteristics (demand uncertainty and market growth) on the performance of innovations.

This study presents evidence from a large number of firms in a varied set of industries, which enables the discovery of principles governing firms which generalize across markets. Nevertheless, this study is subject to typical limitations. The response rate, although typical, can lead to the possibility of response biases. As discussed earlier, a study of differences between early and late responses does not show significant differences between the two samples, suggesting that it is not a problem in this study. The percentage of variance explained, although significant, is not as high as would be desirable. It is especially 
difficult to evaluate the reasons for the part of the variance which is unexplained. The output of the R\&D process is known to be difficult to predict and the lack of correlation between the error terms of the equations when using seemingly unrelated regression indicates that missing variables might not affect the results. Indeed, a number of correlates concerned with multiple aspects of the innovation, the SBU, the firm, and the market did not significantly affect the results. Finally, the performance evaluation is assessed by the same respondant who rates the SBU's strategic orientations. Nevertheless, the risk of common methods bias is minimized due to the fact that the aggregation level is different: while the performance is measured for a specific new product, the strategic orientations are measured at the SBU level. This departs from past new product research which traditionally measures both endogenous and exogenous variables at either the SBU level or at the project level. In spite of these limitations, this research makes theoretical contributions to the marketing strategy literature with significant managerial implications.

\section{Theoretical Implications}

Both the marketing and strategy literatures state that a market orientation and/or a technology orientation increases the commercial performance of an innovation. Yet to date, there have been very few measures of either of them and, hence no systematic analysis of their effects on new product's performance exists. Therefore, no research has studied simultaneously customer, competitive and technological orientations, and their relation to the commercial performance of an innovation. Our model with interactions provides an operational methodology for such a test. Specifically, we contribute to the marketing literature on new product development by (1) considering technological orientation in addition to the other strategic orientations discussed in previous strategic orientation research, (2) viewing interfunctional coordination as a construct distinct from market orientation and (3) evaluating innovation characteristics as a result of the strategic orientation of the firm as well as determinants of the new product commercial performance. 


\section{Managerial Implications}

This research shows the relations between a new product's performance and the orientation of the firm: a consumer orientation, a competitor orientation and a technology orientation. The results can be summarized as follows: (1) A firm wanting to develop an innovation superior to the competition must have a strong technological orientation. (2) A competitive orientation is recommended in high growth markets to enable firms to emphasize innovation costs, thereby developing innovations with lower costs. (3) Firms should be consumer oriented and technology oriented in markets where demand is relatively uncertain. These orientations will lead to better products which will perform better, and the firm will be able to market innovations better, thereby achieving a superior level of performance. (4) A competitive orientation is recommended to market innovations when demand is not too uncertain and in growing markets but should be de-emphasized in highly uncertain markets and in declining markets. Therefore, the recommendations as to the strategic orientation to emphasize are not unconditional, even for the role of the marketing concept. This study provides some guidelines as to which strategic orientation or combination leads to superior performance, depending on the market facing the firm. This study also raises a question as to why it is that, although consumer orientation enables a firm to market an innovation more effectively in certain environments, consumer orientation does not have a significant impact on the innovation's characteristics. While it is clear that innovations are often driven by R\&D, the interface of marketing and $R \& D$ is still often problematic, as discussed earlier. The mechanisms considered in the measure of interfunctional coordination appear to be insufficient to promote the benefits that should be derived from the consumer orientation represented by marketing departments. Similarly to recent work which analyses which practices contribute to developing a market orientation (Ruekert 1992), future research should follow Griffin and Hauser (1994) in studying the processes that contribute to marketing and R\&D integration. Nevertheless, this study demonstrates that a consumer orientation is particularly useful to market an innovation in environments where demand is uncertain. 


\section{END NOTES}

1. The performance or success of an innovation is viewed throughout this study as a relative concept vis-avis the performance of new products marketed by competitors. Consequently, we are not concerned with the explanations of differences in performance due to industry factors, but, instead, we concentrate on competitive and strategic explanations.

2. While the distinction has also been made between process and product innovations, this study is only concerned with new products introduced to the market by a firm.

3. It might be argued that firms in different environments should emphasize different orientations in order to design innovations that have the characteristics required to be successful. Although these interactions were tested for exploratory purposes, theoretical explanations for these effects were difficult to develop. In fact, the empirical analysis revealed that, in general, these interactions are statistically insignificant.

4. While aggregate measures of new product performance at the firm level have been used in prior studies, such as the percentage of profits or sales from new products (Griffin and Page 1993), the necessity to explicitly recognize the role played by the innovation characteristics prevents the use of aggregate new product activities. This would require aggregate measures of new product characteristics (such as in PIMS) which are difficult to assess and which add uncontrolled for variance.

5. Because the unit of analysis is the firm or SBU, variability in the measures can only be obtained by gathering data on a relatively large number of firms/SBU's, which excludes the feasibility of obtaining multiple informants who are typically used in a depth analysis of a few firms.

6. The mean time since introduction of the innovation is 2.75 years, with $47.5 \%$ of the sample having been introduced within the last year, $74 \%$ within two years and $83 \%$ within three years. This gives sufficient time to marketing managers to assess the performance of the new product in the market.

7. Other variables were introduced to control for industry or firm/SBU specific factors (e.g., extent of barriers to entry, firm size, length of time since introduction) as well as industry dummy variables but were not significant.

8. The growth rate in the sample varies from $-20 \%$ to $+116 \%$. 


\section{REFERENCES}

Albernathy, William J. (1978), The Productivity Dilemma: Roadblock to Imnovation in the Automobile Industry, Baltimore, MD: The John Hopkins University Press.

Anderson, Erin (1985), "The Salesperson as Outside Agent or Employee: A Transaction Cost Analysis," Marketing Science, 4, 3, 234-254.

Anderson, P. and M. L. Tushman (1991), "Managing Through Cycles of Technological Change", Research Technology Management, 34, 26-31.

Anderson, Philip and Michael L. Tushman (1990), "Technological Discontinuities and Dominant Designs: A. Cyclical Model of Technological Change," Administrative Science Quarterly, 35, 604-633.

Armstrong, J. Scott and Terry S. Overton (1977), "Estimating Non-Response Bias in Mail Surveys," Joumal of Marketing Research, 14, 3 (August), 396-402.

Bain, J. S. (1959), Industrial Organization, New-York, NY: J. Wiley.

Burgelman, R. A. and L. R. Sayles (1986), Inside Corporate Innovation: Strategy, Structure and Managerial Skills, New-York, NY: Free Press.

Calantone, Roger J., C. Anthony di Benedetto and Richard Divine (1993), "Organisational, Technical and Marketing Antecedents for Successful New Product Development." $R \& D$ Management, 23, 4, 337 351 .

Capon, Noel, John U. Farley and Scott Hoenig (1990), "Determinants of Financial Performance: A MetaAnalysis," Management Science, 36, 10 (October), 1143-1159.

Capon, Noel, John U. Farley, Donald R. Lehmann and James M. Hulbert (1992), "Profiles of Product Innovators Among Large U.S. Manufacturers," Management Science, 38, 2 (February), 157-169.

Carpenter, G. S. and K. Nakamoto (1989), "Consumer Preferences Formation and Pioneering Advantage", Journal of Marketing Research, 26, 285-298.

Chow, Gregory (1960), "Tests of Equality Between Sets of Coefficients in Two Linear Regressions," Econometrica, 28, 591-605.

Cooper, Lee G. and Masao Nakanishi (1983), "Standardizing Variables in Multiplicative Choice Models," Journal of Consumer Research, 10, June, 96-108.

Cooper, Robert G. (1994), "New Products: The Factors that Drive Success," International Marketing review, 11, 1, 60-76.

Cooper, Robert G. (1988), "Predevelopment Activities Determine New Product Success," Industrial Marketing Management, 17, 237-247. 
Cooper, Robert G. (1984), "New Product Strategies: What Distinguishes the top performers?", Journal of Product Innovation Management, 2, 151-164.

Cooper, Robert G. (1984), "The Strategy-Performance Link in Product Innovation," R\&D Management, 14, 4 (Oct.), 247-259.

Cooper, Robert G. (1983), "A Process Model for Industrial New Product Development", IEEE Transactions on Engineering Management, 30, 2-11.

Cooper, Robert G. (1979 a), "The Dimensions of Industrial New Product Success and Failure," Journal of Marketing, 43, Summer, 93-103.

Cooper, Robert G. (1979 b), "Identifying Industrial New Product Success: Project Newprod", Industrial Marketing review, 8, 124-135.

Day, George S. (1994), "The Capabilities of Market-Driven Organizations," Joumal of Marketing, 58, 37 52.

Day, George S. (1991), "Learning About Markets," Report Number 91-117, Cambridge, MA: Marketing Science Institute.

Day, George S. (1990), Market Driven Strategy: Processes for Creating lalue, New-York, NY: Free Press.

Day, George S. (1984), Strategic marketing Planning, New York, NY: West Publishing Company.

Deshpandé, Rohit, John U. Farley and Frederick E. Webster (1993), "Corporate Culture, Customer Orientation, and Innovativeness in Japanese Firms: A Quadrad Analysis," Journal of Marketing, 57, 1 (January), 23-27.

Dess, G. S. and R. B. Robinson (1984), "Measuring Organizational Performance in the Absence of Objective Measures," Strategic Management Journal, 5, 265-273.

Dewar, R. D. and J. Dutton (1986), "The Adoption and Incremental Innovations: an Empirical Analysis", Management Science, 32, 11, 1422-1433.

Dougherty, D. (1990), "Understanding New Markets for New Products", Strategic Management Journal, $11,59-78$.

Doyle, P., J. Saunders and L. Wright (1989), "A Comparative Study of US and Japanese Marketing Strategies in British Market," International Journal of Research in Marketing, 5, 165-273.

Garud, R. and A. H. Van de Ven (1989), "Technological Innovation and Industry Emergence: The case of Cochlear implants", in A. H. Van de Ven, H. L. Angle and M. S. Poole, eds., Research on Management of Innovation, New-York, NY: Harper and Row, 489-532.

Gatignon, Hubert, Erin Anderson and Kristian Helsen (1989),"Competitive Reaction to Market Entry: Explaining interfirm differences", Journal of Marketing Research, 25, 44-55. 
Gatignon, Hubert and Thomas S. Robertson (1993), "The Impact of Risk and Competition on Choice of Innovations," Marketing Letters, 4, 3 (July), 191-204.

Gatignon, Hubert and Thomas S. Robertson (1991), "Innovative Decision Process", in Thomas S. Robertson and Harold H. Kassarjian, eds., Handbook of Consumer Behovior, Englewood Cliffs, NJ: PrenticeHall, Inc., 316-348.

Gatignon, Hubert and Thomas S. Robertson (1985), "A Propositional Inventory for New Diffusion Research," Journal of Consumer Research, 11, March, 849-867.

Gatignon, Hubert and Thomas S. Robertson (1989), "Technology Diffusion, An Empirical Test of Competitive Effect", Journal of Marketing, 53, 35-49.

Gatignon, Hubert, Barton A. Weitz and Pradeep Bansal (1990), "Brand Introduction Strategies and Competitive Environment", Journal of Marketing Research, 27, 390-401.

Geroski. Paul, Steve Machin and John Van Reenen (1993), "The Profitability of Innovating Firms," RAND Journal of Economics, 24, 2 (Summer), 198-211.

Griffin. Abbie and John R. Hauser (1994), "Integrating Mechanisnss for Marketing and R\&D," Report Number 94-116, Cambridge, MA: Marketing Science Institute.

Griffin. Abbie and John R. Hauser (1993), "The Voice of the Customer," Marketing Science, 12, 1, 1-28.

Griffin, Abbie and John R. Hauser (1992), "Patterns of Communication Among Marketing, Engineering and Manufacturing: A Comparison Between Two New Product Teams," Management Science, 38, 3, 360-373.

Griffin. Abbie and Albert L. Page (1993), "An Interim Report on Measuring Product Development Success and Failure," Joumal of Product Innovation Management, 10, 291-308

Henderson, Rebecca M. and Kim B. Clark (1990), "Architectural Innovation: The Reconfiguration of Existing Product Technologies and the Failure of Established Firms," Administrative Science Quarterly, 35, 9-30.

Holak. Susan L. (1988), "Determinants of Innovative Durables Adoption: An Empirical Study With Implication for Early Product Screening," Joumal of Product Innovation Management, 5, 50-69.

Kanter, R. M. (1988), "When a Thousand Flowers Bloom: Structural, Collective, and Social Conditions for Innovation in Organization", in B. M. Staw and L. L. Cummings, eds., Research in Organizational Behavior, Vol 10, Greenwich, Conn: JAI Press, 169-211.

Kelly, Kevin (1994), Out of Control: The Rise of Neo-biological Civilization, Reading, MA: AddisonWesley.

Kohli, A. K and B. J. Jaworski (1990), "Market Orientation: The Construct, Research Propositions, and Managerial Implications", Journal of Marketing, 54, 1-18. 
Kholi, Ajay K., Bernard J. Jaworski and Ajith Kumar (1993), "MARKOR: A Measure of Market Orientation," Jourmal of Marketing Research, 30, 4 (November). 467-77.

Kotler, Philip (1984), Marketing Management: Analysis, Planning and Control, Fourth Edition, Englewood Cliffs, NJ: Prentice-Hall, Inc.

Kotler, Philip (1976), Marketing Management: Analysis, Planning and Control, Third Edition, Englewood Cliffs, NJ: Prentice-Hall, Inc.

Levitt, Theodore (1980), "Marketing Success Through Differentiation of Anything," Harvard Business Review, 58, January-February, 83-91.

Levitt, Theodore (1960), "Marketing Myopia," Hanard Business Review, 38. 4, 45-56.

Lilien, G. and E. Yoon (1988), "Determinants of New Industrial Product Performance: A Strategic Reexamination", IEEE Transactions on Engineering Managemem. 36, 3-10.

Miller, Danny ahd Peter H. Friesen (1982), "Innovation in Conservative and Entrepreneurial Firms: Two Models of Strategic Momemtum," Strategic Management Joumal, 3. 1-25.

Moenaert, Rudy K., William E. Souder, Amoud De Meyer, and Dirk Deschoolmeester (1994), "R\&DMarketing Integration Mechanisms, Communication Flows, and Innovation Success," Journal of Product Innovation Management, 11, 31-45.

Montoya-Weiss, Mitz M. and Roger Calantone (1994), "Determinants of New Product Performance: A Review and Meta-Analysis," Journal of Product Innovation Management, 11, 397-417.

Nadler, David A. and Michael Tushman (1980), "Organization, Congruence, and Effectiveness," Organizational Dynamics, Autumn, New York, NY: American Management Association.

Narver, J. C. and S. F. Slater (1990), "The Effect of a Market Orientation on Business Profitability", Journal of Marketing, 20-35.

Parker, P. M. and M. Sarvary (1994), "An Integrated and Cross-Cultural Study of Diffusion Theory," Working Paper, Fontainebleau, France: INSEAD.

Porter, M. (1980), Competitive Strategy, New York, NY: The Free Press.

Porter, M. (1985), Competitive Advantage, New York, NY: The Free Press.

Ramaswamy, Venkatram, Hubert Gatignon and David J. Reibstein (1994), "Competitive Marketing Behavior in Industrial Markets," Journal of Marketing, 58, April, 45-55.

Robertson, T. S. (1971), Innovative Behavior and Communication, New York, NY: Holt, Rinehart \& Winston.

Robertson, T. S. and H. Gatignon (1986), "Competitive Effects on Technology Diffusion", Journal of Marketing, 50, 1-12. 
Robinson, W. T. (1988), "Marketing Mix Reactions to Entry," Marketing Science, 7, 4 (Fall), 368-385.

Robinson, W. T. and C. Fornell (1985), "The Sources of Market Pioneer Advantage in Consumer Goods Industry" Journal of Marketing Research, 22, 305-317.

Rogers, E. M. (1983), "Diffusion of Innovations", New York, NY: The Free Press.

Rothwell, R. (1977), "The Characteristics of Successful Innovators and Technically Progressive Firms", $R \& D$ Management, 7, 191-206.

Rothwell, R., C. Freeman, A. Horsley, V. Jervis, A. Robertson and J. Crawford (1979), "SAPPHO Updated. Project SAPPHO Phase II", Research Policy, 3, 258-291.

Ruekert, Robert W. (1992), "Developing a Market Orientation: An Organizational Strategy Perspective," International Journal of Research in Marketing. 9, 225-245.

Saunders, John, Michael Brown and Stuart Laverick (1992), "Research Notes on the Best British Companies: A Peer Evaluation of Britain's Leading Firms," British Journal of Management, 3, 181 195.

Saxe, R. and B. A. Weitz (1982), "The SOCO Scale: A Measure of the Customer Orientation of Salespeople", Journal of Marketing Research, 343-351.

Scherer, F. M. (1980), Industrial Market Structure and Economic Performance, Chicago, IL: Rand McNally.

Schnaars, Steven P. (1994), Managing Imitation Strategies: How Later Entrants Seize Markets from Pioneers, New York, NY: The Free Press.

Shane, Scott A., S. Venkatraman and Ian C. MacLillan (1994), "The Effects of Cultural Differences on New Technology Championing Behavior Within Firms," The Joumal of High Technology Management Research , 5, 2, 163-182.

Slater, Stanley F. and John C. Narver (1994), "Does Competitive Environment Moderate the Market Orientation-Performance Relationship?, Journal of Marketing, 58, 1 (January), 46-55.

Soni, Praveen K., Gary L. Lilien and David T. Wilson (1993), "Industrial Innovation and Firm Performance: A Re-conceptualization and Exploratory Structural Equation Analysis," International Journal of Research in Marketing, 10, 365-380.

Thompson, James D. (1967), Organizations in Action, New York, NY: Mc Graw-Hill Book Company.

Urban, G. L., T. Carter, S. Gaskin and Z. Mucha (1986), "Market Share Rewards to Pioneering Brands: An Empirical Analysis and Strategic Implications," Management Science, 32 (June), 645-659.

Van de Ven, A. (1986), "Central Problems in the Management of Innovation", Management Science, 32, 590-608. 
Venkatraman, N. and V. Ramanujam (1986), "Measurement of Business Performance in Strategic Research: A Comparison of Approaches," Academy of Management Review, 11, 4, 801-814.

von Hippel, E. (1986), "Lead users: A Source of Novel Product Concepts", Management Science, 32, 791 805.

von Hippel, E. (1988), The sources of innovation, New York, NY: Oxford University Press.

Waldman, David A. and Leanne E. Atwater (1994), "The Nature of Effective Leadership and Championing Processes at Different Levels in a R\&D Hierarchy," The Journal of High Technology Management Research, 5, 2, 233-246.

Workman, John P. (1993), "Marketing's Limited Role in New Product Development in One Computer Systems Firm," Journal of Marketing Research, 30, 4 (November), 405-21.

Xuereb, J.-M. (1993), "Stratégies d'Innovation Dans les Secteurs de Haute Technologie: Le Piège du Marché Virtuel," Recherche et Applications en Marketing, 8, 2, 23-44. 
Table 1 - Distribution of Industries Represented in Sample

\begin{tabular}{|l|c|}
\hline Industries & Percentage of Sample \\
Food Products & 9.0 \\
Tobacco Products & 0.3 \\
Textile Products & 2.8 \\
Fumiture \& Fixture Products & 4.4 \\
Paper Products & 6.4 \\
Chemical Products \& Pharmaceuticals & 6.2 \\
Rubber and Plastics & 3.6 \\
Industrial and Conunercial Machinery & 17.5 \\
Electronic and Other Electrical Products & 23.7 \\
Commercial Services Transportation Equipment & 4.4 \\
Measuring and Analyzing Instruments & 3.3 \\
Medical & 2.3 \\
Miscellaneous & 16.1 \\
\hline
\end{tabular}


Table 2 - Measures of Major Constructs and Their Reliability

INNOIATION SUCCESS AND CHARACTERISTICS

O Innovation Secoess (NEW FRODUCT PERFOKMLANCE) $\rightarrow=-82$

- The grouth of this new prodocts market share is superior to the unwkel share gronth of its main competion

- With this new product ue bave increased our manter share in this calezory

- Kelative to other prodacts of our fim. this one has a better return on investruent

- Relative 10 our competilors products, this one has a better retum on investmeat

- This new product has suecueded in achioving its main objectives

0 Iroduct Advantzge $\rightarrow *=.74$

- Overall advanteer

- Product pedormano

- Product desizn (functionalin, fearures)

- Product positionille (product imec)

- Reputation

- Product qualiti

- Incromental versus Radical $-a=\$ 4$

- This new product is a minor injpovenent in a current technology

- This new product has changed the narlet conditions

- This new product is one of the fint applications of $u$ technolveical breakthrough

- This new product is based an a revolutionary cheree in techuology

- This new product inconorated a large aew body of technologeded kionledge

- This new product bas cheresd the nature of conpecioin

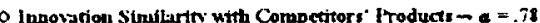

- ONerall, this new product is very sinilas to our min competions' products

- The tectunology of this new product is very sinular 10 che teclunology of our main competiturs' produet

- The positioning of this nex prodact is very similar to the positionine of our mein competitors products

- The applications of this nesv product are lotally different from applications of ous main contpetions products

- From the point of view of the uker. this new product is cotaly different from our nian competitors' mroducts

O Innovation Rejative Cost $\rightarrow \alpha=.73$

- Marketine costs

- Manufacturine/Operations

- Kesearch and Diviopmin

- (verall costs

FIRM ORIENTATION

o Customer Oricntation (Narver and Slater 1990. Slater and Narver 1992) $-a=.85$

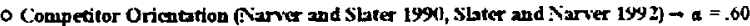

O Tectuologkel Orkentation $-\alpha=.89$

- Our SBU uses sophisticated tectunologies in its new product developniten

- Ous new products are atuars at the state of the an of the technoloey

- Out SBU is very proactive in the development of newriechnologius

- Our SBU has the will and the capacity to build and to niariet a lechnological breahthrough

- Oux SBU bas buit a large and strong network of r dationships with supptiers of lechnological equipmen

- Our SBU bas en ezressie technolozical patent stratsey

- Our SBU bas betler industial methods than the comprticion

- We bave a bette conpective knouledge than our competitor

- Kedative to our competions, our new prodncts are more ambitious

- Relative to our competitoss, our R\&D programs are nore ambitious

- Our SBU is Very prowstive in the construction of new technical solutions to answe users' neods

- Onf fim is always the first one to use a new techrology for its new product developtacat

0 Interfunctional Coordination (Nianer and Slater 1990, Sbater and Naner 1992) $-\propto=.77$

MARKET CHARACTERISTICS

- Martier Gronth

- Annual growth rate of the niarket in the catesory at the time you launched the new product

0 Conipertion lntenrity $\rightarrow=.79$

- Competicion in our industry is carthroat

- There are many price uars in our industry

- Compered 10 the idine industry utich is very competitive (very high competition intensity, how is the intensity of competition in this caterory? (Ven low-Var trieb)

o Demand Uboertainty $\rightarrow a=.60$

- If it is very difficalt to predict the demand for movies but very easy to predict the demand for detergents, to what extent do you agrec

with the statenent that demend is diffedt to prodict in this coleg ory"

- Custorner uster an be assessod relatively accuratdy in this category

- Demand is fidy essy to forecest in this calugon

- The evolution of custome preference is difficali to predict in this catezory

FIRM RESOURCES

O Mrm Relative Rerources $\rightarrow \approx=.83$

- Levd of Overall resources

- Levid or Marketing resources

- Levd of Distribution und Salexforce tesources

- Iavd of Keserch and Devedoprient resource 
Table 3 - Parameter Estimates (OLS)

\begin{tabular}{|c|c|c|c|c|c|c|c|c|c|c|}
\hline & Produrt & Advantage & Product & K2dibalues: & Product & Sinulturthy & Product & Const & Innovartors & Performance \\
\hline Prodketor Vartahker & Puram & $T-s a t$ & l'arian & $T-x: a t$. & Param & $T$-stat. & Paranu & T-stit. & P'ar:m & T-Stat. \\
\hline Cinstant & $-\therefore 01$ & -0.61 & $-10.1^{\mathrm{n}}$ & -2.33 & -0.08 & -1.8 .3 & 0.055 & 1.11 & 0.003 & 0.07 \\
\hline P'dt. Advantage & - & & - & & - & & - & & $0.32^{*}$ & 5.19 \\
\hline I'd. Radicalnass & - & & - & & - & & - & & $0.21^{4}$ & 3.63 \\
\hline Pct. Similarity & - & & - & & - & & - & & $-0.12^{i v}$ & -2.19 \\
\hline Pat Cists & - & & - & & - & & - & & $-0.28^{n}$ & -5.81 \\
\hline $\begin{array}{l}\text { Cimsumet } \\
\text { Oriontation }\end{array}$ & & & & & & & & & & \\
\hline Cinstint & $\therefore 1 \%$ & 1.25 & -0.11 & -3.76 & 0.12 & 1.76 & -0.07 & -0.84 & -0.062 & $-0.7 s$ \\
\hline Groudr & - & & - & & - & & 0.007 & 1.43 & -0.007 & -1.55 \\
\hline Competition & - & & - & & - & & -0.099 & -1.24 & 0.016 & 0.22 \\
\hline Uncurtinty & - & & - & & - & & 0.070 & 0.7 .3 & $0.185^{11}$ & 2.10 \\
\hline $\begin{array}{l}\text { Computition } \\
\text { Orintation }\end{array}$ & & & & & & & & & & \\
\hline Cinstiont & 0.01 & 0.15 & -0.01 & -0.13 & 0.04 & .049 & 0.027 & 0.27 & -0.030 & -0.3 .3 \\
\hline Growth & - & & - & & - & & $-0.015^{*}$ & -2.97 & 0.005 & 1.20 \\
\hline Cormpetitive & - & & - & & - & & -0.061 & -0.67 & -0.124 & -1.48 \\
\hline Unccrtainty & - & & - & & - & & 0.017 & 0.15 & $-0.270^{\circ}$ & -2.61 \\
\hline $\begin{array}{l}\text { Tochnology } \\
\text { Oricntation }\end{array}$ & & & & & & & & & & \\
\hline Cinstiont & $\therefore=$ & 501 & $0.61 *$ & $10.2+$ & $-0.33^{\circ}$ & -5.25 & $0.1 \mathrm{~s}^{\mathrm{h}}$ & 1.94 & 0.06 & 0.73 \\
\hline Gromuth & - & & - & & - & & 0.002 & 0.46 & 0.001 & 0.25 \\
\hline Compatitice & - & & - & & - & & -0.021 & -0.32 & $0.01 \$$ & 0.29 \\
\hline Uncarrainty & - & & - & & - & & -0.021 & -0.24 & $0.186^{\prime \prime}$ & 2.34 \\
\hline $\begin{array}{l}\text { Interfunctional } \\
\text { Conordination }\end{array}$ & $\therefore 04$ & -0.82 & 0.04 & 0.79 & $-0.11^{\mathrm{N}}$ & -2.08 & -0.10 & -0.173 & 0.096 & 1.85 \\
\hline Growth & - & & $0.02^{\prime}$ & 2.47 & $0.02^{\prime \prime}$ & 2.04 & -0.014 & -1.25 & -0.005 & -0.50 \\
\hline $\begin{array}{l}\text { Cumpaitive } \\
\text { Intensity }\end{array}$ & - & & -0.01 & -0.26 & $0.13^{4}$ & 3.20 & -0.002 & -0.04 & -0.002 & -0.05 \\
\hline $\begin{array}{l}\text { Demind } \\
\text { Uncertainty }\end{array}$ & - & & $0.12^{\circ}$ & 2.60 & $-0.12^{\circ}$ & -2.33 & $0.12^{b}$ & 2.17 & -0.05 & -0.94 \\
\hline Firm Resources & $\left(.21^{\circ}\right.$ & 5.66 & -0.07 & -1.55 & -0.09 & -1.88 & $0.15^{4}$ & 3.08 & $0.14^{x}$ & 2.94 \\
\hline $\mathrm{R}^{2}$ & $\therefore 23$ & & 0.27 & & 0.17 & & 0.15 & & $\begin{array}{l}0.37 \\
371\end{array}$ & \\
\hline
\end{tabular}

"Statistically significant $x$ the 0.01 level.

"Statistically signifiem $\Sigma$ the 0.05 level. 
Figure 1 - A Conceptual Model of New Product Success

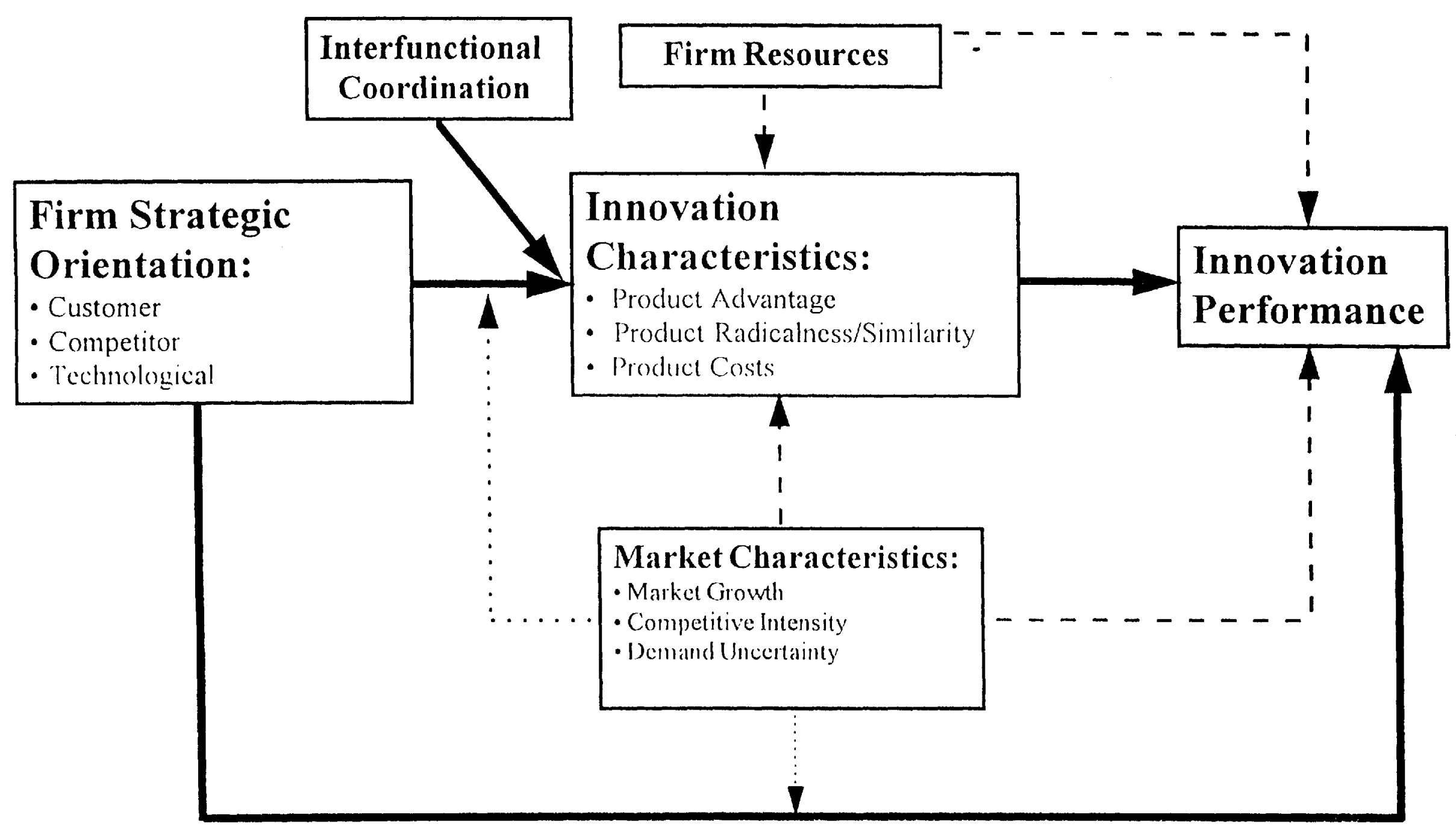

